УДК: 66.097.3-039.7

\title{
Кохан I.B.
}

\section{ГАЗОРІДИННІ РЕАКТОРИ ДЛЯ ПРОЦЕСУ КАТАЛІТИЧНОЇ ГІДРАТАЦІЇ АЦЕТИЛЕНУ}

\begin{abstract}
Об'єктом наукового інтересу автора иієї статті є розробка процесів основного органічного синтезу, в яких застосовується гомогенний металокомплексний каталіз. Для проведення такого типу процесів, застосовують газорідинні реактори. Зокрема, автором досліджується каталітична гідратація ацетилену на гомогенному каталізаторі, розчиненому у воді. В такому випадку каталітична система з води та розчиненого в ній каталізатора знаходиться у рідкій фазі, через яку барботується газ ацетилен. Під час проведення досліджень пов'язаних із інжсинірингом зазначеного прочесу вирішується широке коло практичних задач. Зокрема є необхідність у різноманітних кінетичних вимірюваннях, у визначенні оптимальних режимів проведення процесу, підбору додаткових розчинників та со-каталізаторів. Також важливою частиною інжинірингу процесу $\epsilon$ вибір оптимальної гідродинамічної обстановки для проведення реакиії. Для успішного проведення всього иього комплексу досліджень, необхідно мати відповідні дослідні реакторні вузли. Саме потреба в таких дослідних газорідинних реакторах різного типу для проведення зазначених досліджень стала причиною за якою автором був розроблений універсальний дослідний реактор із можливістю зміни гідродинамічної обстановки. Отже у цій роботі представлені результати проектування, конструювання, виготовлення та застосування у процесах основного органічного синтезу зазначеного реактора. Особливістю реактора, розробленого автором, є застосування таких конструктивних рішень, які дозволяють змінювати гідродинамічну обстановку й проводити дослідження з гідродинаміки, теплообміну $і$ масообміну газорідинних реакиій при різних умовах. Також в статті наводяться приклади арматурного оформлення реактора, щчо дозволяє ефективно проводити експериментальні роботи $і$ виконувати необхідні технологічні операції здійснювати технологічні вимірювання та проводити кінетичні дослідження.
\end{abstract}

Ключові слова: основний органічний синтез, гомогенний металокомплексний каталіз, каталітична гідратаиія ацетилену, газорідинний реактор, барботування, газліфт, змійковий реактор.

Актуальність дослідження. Сучасна промисловість основного органічного синтезу постійно знаходиться в пошуку нових синтетичних шляхів як для отримання продуктів цільового призначення так $\mathrm{i}$ для напівпродуктів. При цьому основним оптимізаційним критерієм для розвитку є підвищення економічної ефективності виробництва при одночасному підвищенні якості продуктів і напівпродуктів. Також, важливу роль відіграють економія вихідних речовин (сировини) і зниження енергоспоживання при виробництві, що в результаті призводить до зниження витрат на виробництво. I нарешті, одним із найважливіших цільових критеріїв для розвитку основного органічного синтезу в XXI столітті $є$ такі удосконалення процесів, що позитивно впливають на навколишнє середовище, тобто використання Зеленої хімії. Для вирішення зазначених завдань в галузі хімічної інженерії ведуться активні дослідження, що спрямовані як на створення нових технологічних процесів так й на модернізацію вже існуючих виробництв.

Одним 3 ключових інструментів для вирішення багатьох 3 описаних вище завдань, що стоять перед промисловістю основного органічного синтезу є каталіз. Його значення важко переоцінити, оскільки саме розробка і застосування нових каталізаторів не тільки породжує нові процеси, але і дозволяє абсолютно поновому поглянути на вже існуючі та впроваджені процеси, пов'язані 3 переробкою вихідних речовин традиційних для основного органічного синтезу, таких як ацетилен, ароматичним вуглеводні, алкени, алкани i синтез-газ. По ряду істотних причин, передові дослідження в області каталізу в даний момент сконцентровані на гомогенному металокомплексному каталізі, серед яких зокрема такі, що є об'єктом дослідження автора, а саме каталізатори на аурумі (I). Зазначені каталізатори мають високу селективність, дозволяють проводити реакції з високою конверсією в м'яких умовах, без застосування високих тисків та високих температур. Крім того при правильному підборі лігандів, для багатьох гомогенних металокомплексних каталізаторів вдається досягти водорозчинності, що дозволяє втілити в життя принципи Зеленої хімії й зокрема, уникнути або максимально зменшити застосування органічних розчинників.

Постановка проблеми. Велика кількість вихідних речовин, в основному органічному синтезі є газами, як наприклад ацетилен, етилен, синтез-газ та ін. При цьому багато важливих промислові реакції 3 цими газами проходять в рідкій фазі, в якості якої найчастіше виступає розчинник із розчиненим в ньому каталізатором. Так, наприклад, в промисловому процесі синтезу альдегідів в присутності металокомплексних каталізаторів, добре відомому як гідроформілювання або оксосинтез, взаємодіють ненасичені вуглеводні, а саме етилен та синтезгаз, що являє собою певну стехіометричну суміш $\mathrm{CO}$ й $\mathrm{H}_{2}$ В такому процесі в якості розчинників зазвичай використовують аліфатичні, циклоаліфатичні або ароматичні вуглеводні, в яких власне й розчиняють каталізатор, яким, найчастіше служать карбоніли деяких металів VIII групи періодичної системи (головним чином Co та Rh). В той же час, в реакції синтезу альдегідів взаємодією ацетилену із водою, сама ж вода, що $\epsilon$ одним 3 реагентів, водночас $є$ й розчинником, зокрема для гомогенного металокомплексного каталізатору на 
аурумі (I), що застосовується в такій реакції та досліджується автором. Оскільки гомогенний каталіз все частіше стає об'єктом підвищеного інтересу з боку хімічної індустрії, виникає необхідність в проведенні широкого спектру кінетичних досліджень, пов'язаних із такими процесами, що відбуваються у системі газрідина в присутності різноманітних гомогенних металокомплексних каталізаторів.

Теоретичний аналіз дослідження. Реакційні апарати, призначені для проведення реакцій в системі газрідина, знаходять останнім часом все більше застосування в хімічній інженерії, нагальною стає необхідність щодо введення деякої класифікації таких апаратів. Так, зокрема, відповідно до класифікації, запропонованої в [1], реакційні апарати такого типу можуть бути розділені на наступні групи:

I. Барботажні реактори, в яких газ вводиться в рідину через один або декілька газорозподільних пристроїв - барботерів, в результаті чого й утворюється поверхня контакту фаз.

II. Реактори із диспергуванням газу механічним засобом. У цьому типі реакторів газ, що вводиться до апарату через газорозподільний пристрій диспергується в рідини за допомогою різних типів перемішування.

III. Плівкові реактори, облаштування яких є таким, що контакт газу із рідиною здійснюється таким чином, що рідина знаходиться у вигляді плівки на стінках реактора.

Під час роботи над розробкою процесу каталітичної гідратації ацетилену, автор сконцентрував увагу на реакторах першої групи, а саме на барботажних реакторах, які в свою чергу можуть бути також певним чином класифіковані. Знову ж таки в [1], група I, барботажних реакційних апаратів розділяється на наступні типи:

1. Колонні барботажні реактори.

Реактор цього типу виконується у вигляді колони в нижній частині якої розташовується барботер газорозподільний пристрій. Колона такого реактора встановлюється вертикально і по висоті може бути при необхідності розділена горизонтальними перегородками, призначеними для поліпшення циркуляції рідини всередині реактора. Перевагою реакторів такого типу є простота конструкції, в той час як недоліком є слабка циркуляція рідкої фази і невисока організованість потоків всередині колони. При необхідності, теплообмінна апаратура може бути розміщена як всередині так і ззовні колони реактора.

2. Газліфтні барботажні реактори.

Відмінною особливістю реакторів цього типу $\epsilon$ наявність однієї або декількох газліфтних труб, розташованих усередині колони реактора. У зв'язку з цим газорозподільна система сконструйована таким чином, щоб підведення газу до кожної газліфтної труби здійснювався індивідуально. В цілому ж циркуляція в реакторах такого типу значно краще ніж в колонних барботажних реакторах, що зумовлено наявністю двох потоків, газорідинного висхідного та рідинного низхідного. Газліфтні барботажні реактори $є$ цікавими для застосування в дослідницьких установках зокрема через зручності моделювання. Так, змоделювавши кінетичні умови в одній газліфтній трубі, отримані результати можуть бути поширені в подальшому на більшу, необхідну кількість таких саме труб, розташованих в одній колоні реактора.

3. Барботажні змійкові реактори.

Реактор цього типу за конструкцією значно відрізняється від двох попередніх тим, що виконаний не у вигляді єдиного колонного корпусу, а у вигляді декількох вертикальних труб, з'єднаних послідовно калачами. У такому реакторі газорідинна суміш рухається послідовно то в висхідному, то в низхідному напрямі потоку. Теплообмін в такого типу реакторах виконується зовнішнім.

Мета статті. Ця стаття присвячена опису результатів проектування, конструювання та виготовлення газорідинного реактора із можливістю зміни гідродинамічної обстановки, що призначений для здійснення кінетичних досліджень перебігу реакцій в яких застосовуються металокомплекні каталізатори.

Задачі дослідження. Оскільки для здійснення кінетичних досліджень потрібна спеціально розроблена реакційна апаратура, що дозволяє задовольнити вимоги дослідників, зайнятих в роботі по гомогенному каталізу. Досить часто, на початковому етапі дослідницької роботи, досить важко однозначно визначити тип реактора, який виявиться оптимальним для досліджуваної системи газ-рідина для проведення саме такого каталітичного процесу, як було задумано спочатку. Хімічний інженер-дослідник часто стикається в процесі наукового пошуку, з необхідністю суттєво змінити апаратурне оформлення досліджуваного процесу. Крім того нерідко виникає потреба в зміні гідродинамічної обстановки в реакторі. Додатково, в деяких випадках, інженеру-досліднику необхідно й зовсім змінити тип реакційного вузла, змінивши ємнісний реактор ідеального перемішування на змійковий реактор ідеального витискання.

Крім того, необхідність суттєво змінити гідродинамічну обстановку в реакторі, провести зміни в арматурі або розташуванні вимірювальних датчиків, може виникнути не тільки в процесі первісного пошуку, але й в процесі подальших досліджень, при виборі різних умов проведення кінетичного експерименту, аж до останніх стадій, в яких також необхідно мати можливість провести зміни умов процесу.

Необхідність мати реакційну апаратуру, яка дозволяє швидко проводити необхідні зміни без істотних витрат часу й зусиль, та дозволяє проводити весь комплекс досліджень в області гомогенного металокомплексного каталізу в системах газ-рідина, і спонукали автора розробити описуваний в цій статті газорідинний реактор із можливістю проведення зміни гідродинамічної обстановки. Окрім того, арматурне оформлення реактора було розроблене таким, що дозволяє при необхідності виконати переналаштування арматури й вимірювальних датчиків. При проектуванні, конструюванні та виготовленні реакційного вузла, автор намагався застосовувати уніфіковані рішення, з метою досягти максимально можливої взаємозамінності конструктивних елементів. 
Маючи в своєму розпорядженні два повних набора газорідинних реакторів, описуваних в цій статті, автору вдалося знайти можливості для побудови досить варіативних і зручних для проведення широкого набору кінетичних досліджень установок для дослідження процесів каталітичної гідратації ацетиленових сполук із застосуванням гомогенних металокомплексних каталізаторів.

Викладення основного матеріалу дослідження. Оскільки всі три типи реакторів представляють інтерес для проведення газорідинних реакцій, автором був розроблений реактор єдиної конструкції, який виконаний в єдиному уніфікованому корпусі, з набором взаємозамінних фланцевих кришок з різною кількістю штуцерів. У комплекті розробленого реактора також знаходиться три окремих монтажних набори для установки будь-якого 3 них в корпус реактора. Ці три набори, будучи змонтовані в корпусі по-окремо, дозволяють отримати реактор одного з трьох перерахованих вище типів (барботажний, газліфтний або змійковий).

Розглянемо конструкцію корпусу реактора і фланцевих взаємозамінних кришок зі штуцерами.

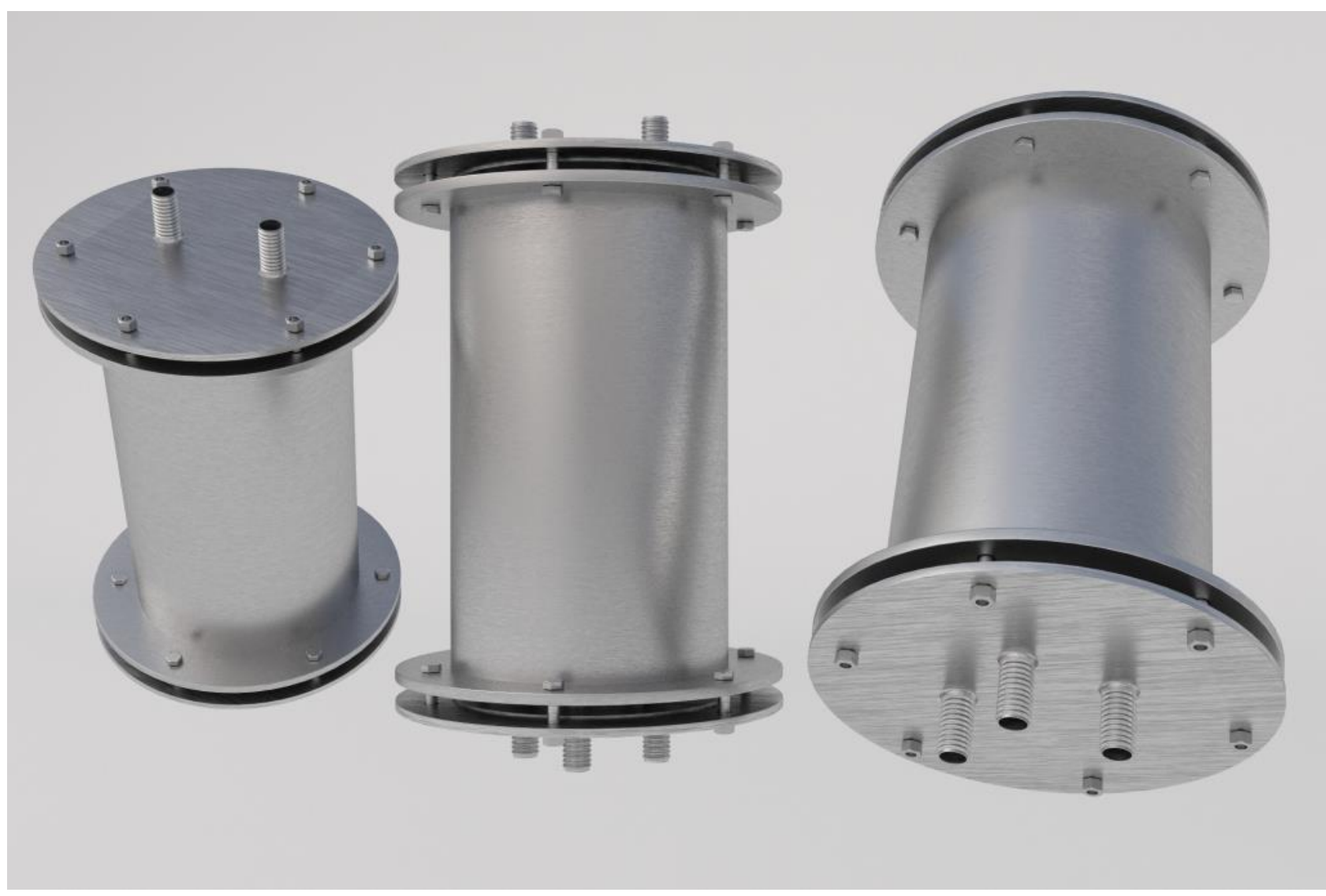

Рисунок 1 - Загальний вигляд реактору з фланцевими кришками.

Корпус реактору складається із зварної обичайки, що виготовлена із нержавіючої сталі 12Х18Н10Т товщиною 3 мм, та двох фланців, також виготовлених із нержавіючої сталі 12Х18Н10Т товщиною 6 мм. Обидва фланці, та обичайка з'єднані шляхом аргонового зварювання, та розраховані на максимально допустимий тиск до 2 атм, незважаючи на те, що реакційний вузол під час дослідів працює за нормального тиску.

Фланці, що розташовані з обох торців обичайки мають по шість отворів діаметром 6 мм, скрізь які відбувається кріплення фланцевих кришок болтами. Фланцеві кришки виготовлені із нержавіючої сталі 12X18Н10Т, й мають відповідні отвори, як і фланці на корпусі. Конструкція наявних кришок різниться кількістю штуцерів, яких може бути два або три. При необхідності, можуть бути виготовлені відповідні кришки й на більшу кількість штуцері.

Кріплення кришок до фланців відбувається шістьма болтами з різьбою М6, таким чином, що головка болта знаходиться 3 боку фланця, а зручні для закручування закрутки, або гайки, розташовуються 3 боку кришки для зручності монтажу.

Конструкція штуцерів типова. 3 метою забезпечення герметичності з’єднання, кожний штуцер має нарізану різьбу $1 / 2$ дюйма, що дозволяє підключати стандартні газові та рідинні шланги.

Розглянемо три можливі види оснастки що можуть бути змонтовані в корпусі реактора.

Найбільш широко вживаним як в промисловій так й в лабораторній практиці а також та простішим за монтажем, є колонний барботажний реактор, в якому розпилення газу у рідині відбувається за допомогою барботеру. 


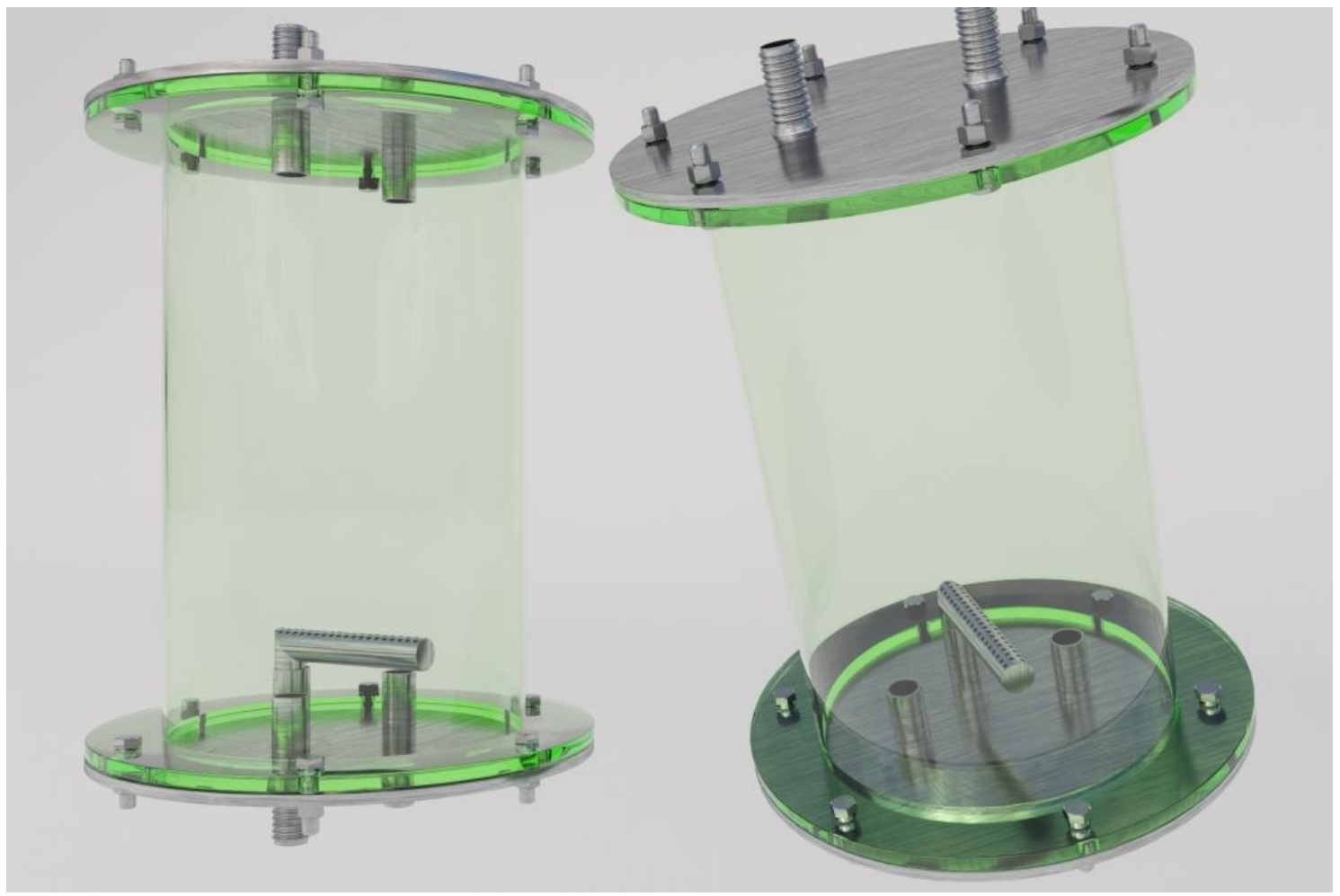

Рисунок 2 - Облаштування колонного барботажного реактору.

Барботер, у вигляді невисокої Г-подібної трубки має систему отворів, розташованих у верхній частині горизонтального відрізку. Отвори розташовані у шаховому порядку. Серед переваг такої системи слід зазначити простоту конструкції та легкість монтажу. В той же час у такого типу облаштування $є$ основний недолік, нерівномірність перемішування газорідинної суміші як по висоті так й по ширині об'єму реактора.

Другим типом реактору, що може бути змонтований на основі пропонованого набору комплектуючих $\epsilon$ газліфтний барботажний реактор. Внутрішне гідродинамічне облаштування такого реактору складається із набору вертикальних труб, в нашому випадку із трьох, де в нижній частині кожної, розташовано окремий розпилювач-барботер точкового типу, що подає потік розпиленого газу в нижню частину кожної окремої труби.

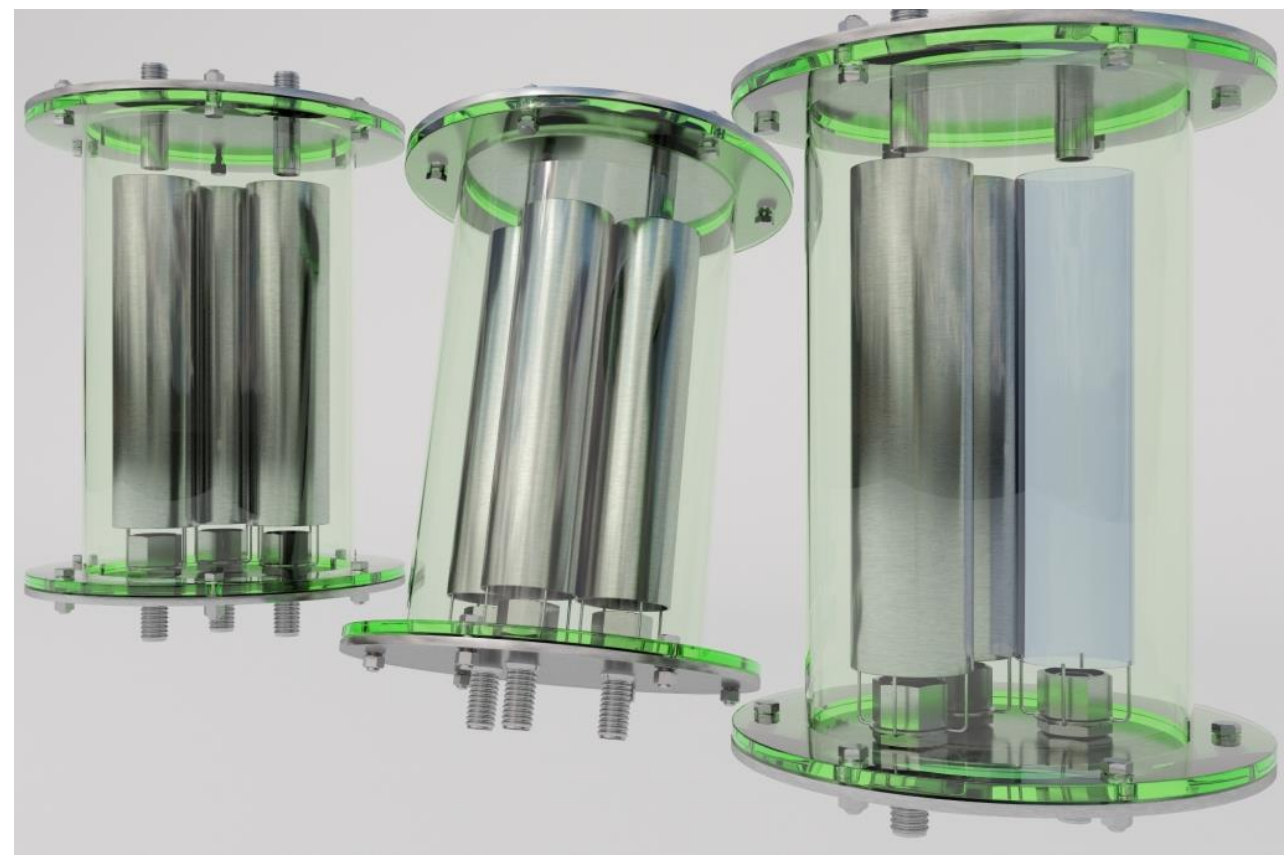

Рисунок 3 - Облаштування газліфтного барботажного реактору на три труби.

Таким чином значно покращується як горизонтальне так і вертикальне перемішування в робочому об'ємі реактора. В той же час слід зазначити, що недоліком зазначеного типу реакторів $є$ складність виготовлення та монтажу. 
Третім типом реактору є барботажний змійковий реактор. Такий тип реактору відрізняється від двох вищеописаних за типом, оскільки є реактором близьким до реактору ідеального витіснення, на відміну від того, що перші два реактора наближуються до реакторів ідеального змішування. Отже в цьому, третьому типі реактору газорідинний потік переміщується по змійковій трубі, в якій відбувається як змішування так й реакція.

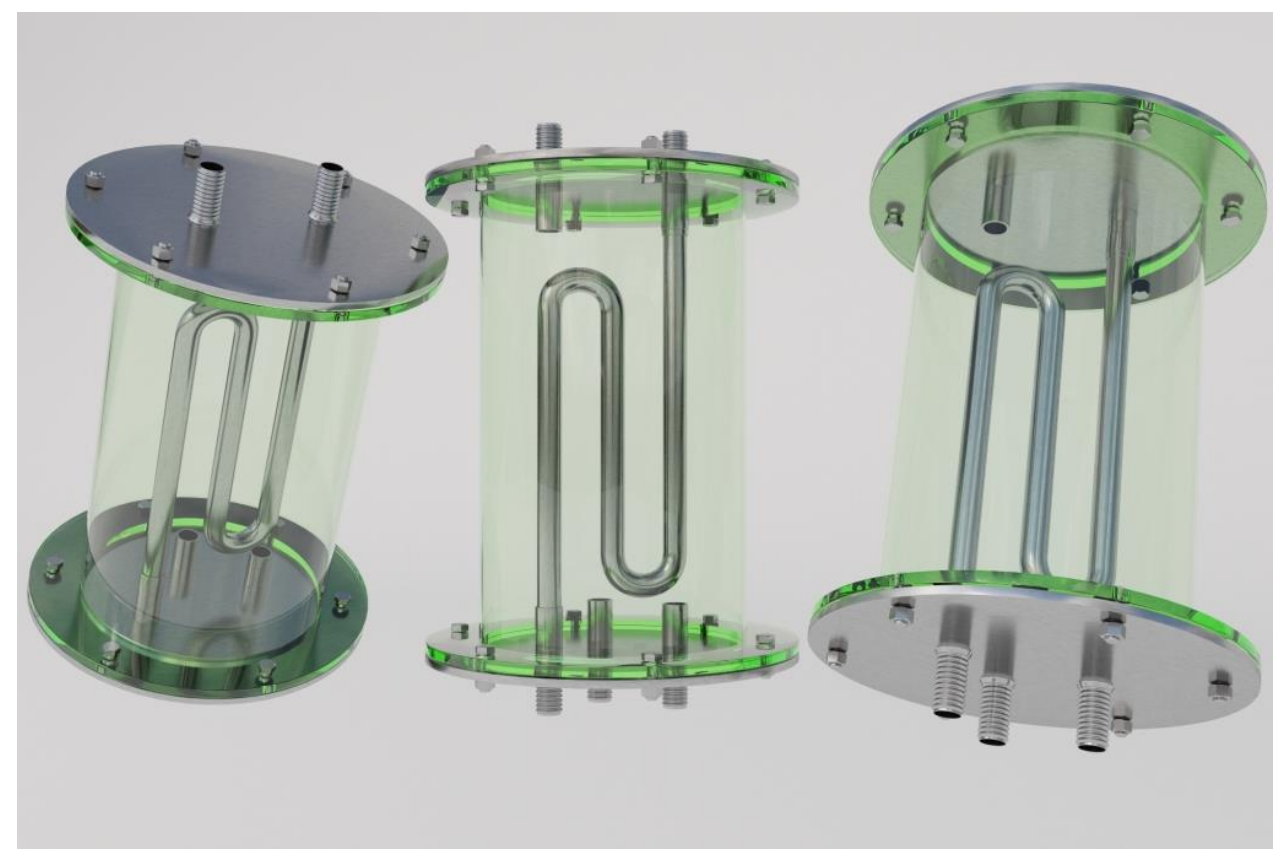

Рисунок 4 - Облаштування змійкового реактору.

В такому реакторі крізь корпус пропускається теплоносій, що здійснює нагрівання власно змійкового реактору до температури, $60-65{ }^{\circ} \mathrm{C}$, необхідної, згідно досліджень автора, для проведення каталітичної гідратації ацетилену. Серед переваг розглянутого типу облаштування, слід зазначити можливість проведення досліджень у значно іншій гідродинамічній обстановці що розширює можливості досліджень. Щодо недоліків зазначеного типу облаштування, то це є невеликий робочій об'єм зміївика.

Отже розглянуті три можливі типи облаштування дозволяють на одній матеріальній базі проводити дослідження реакцій в різноманітних умовах.

По завершенні виготовлення деталей корпусу реактора, а саме обичайки та двох фланців, вони були зібрані за допомогою аргонового зварювання [2], після чого виникла необхідність в ретельному очищенні деталей корпусу реактора.

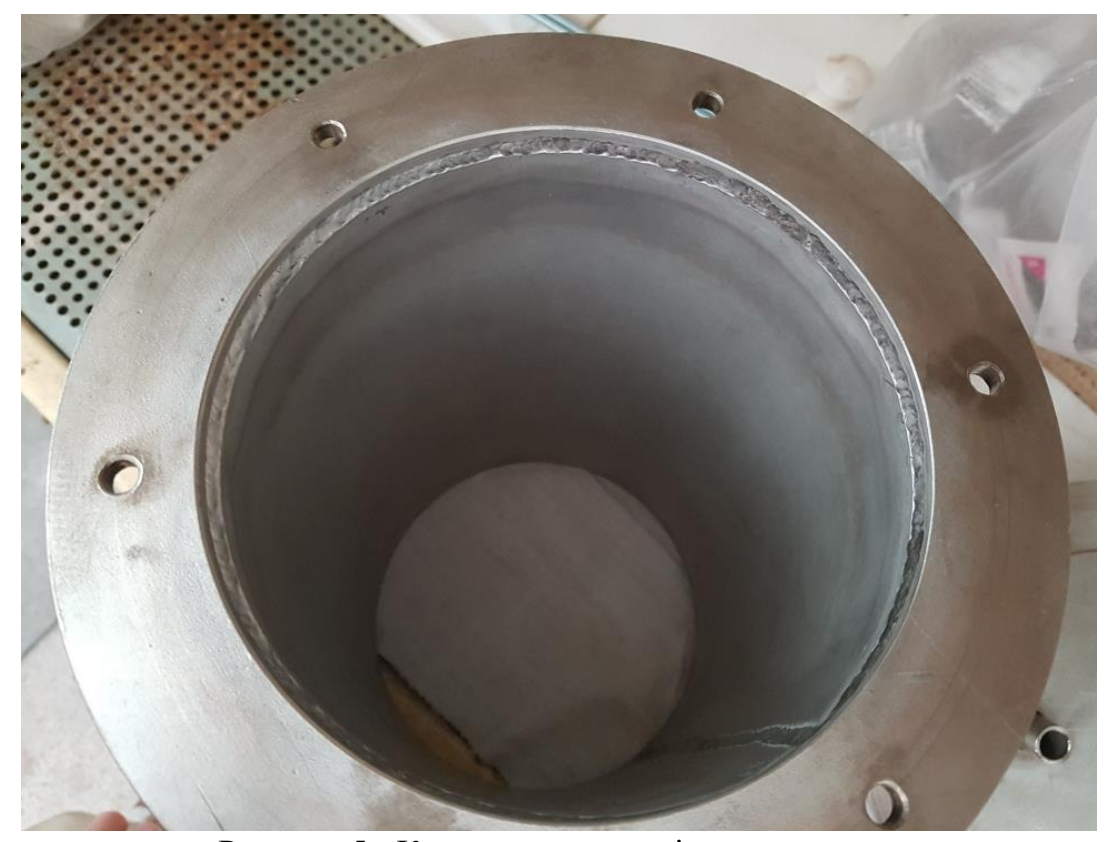

Рисунок 5 - Корпус реактору після очищення. 
В промислових умовах, за наявності відповідного обладнання очищення таких деталей проводиться за допомогою електрополірування. В лабораторних умовах, зважаючи на доступні матеріали, була проведена наступна процедура очищення.

Спочатку, нерівності, подряпини й окалину, 3 деталей корпусу реактора, знімали за допомогою металічної щітки, яку обертали за допомогою електричного дрилю, в результаті чого провели попередню підготовку поверхонь. Далі, металічну щітку замінили диском із наждачним папером, а після того, як всі поверхні корпусу реактора були оброблені таким чином, додатково шліфували насадкою із тканиною, яку обертали також за допомогою дрилі.

Після завершення механічної обробки деталей корпусу реактора, проводили очищення поверхонь деталей хімічними засобами. А саме, протирали зазначені поверхні сумішшю бензину «Калоша» і спирту етилового у співвідношенні 1:1. Далі для внутрішньої поверхні реактора провели протравлення в розчині наступного складу: 100мл $\mathrm{H}_{3} \mathrm{PO}_{4}$ : 5мл $\mathrm{HF}: 250$ мл $\mathrm{H}_{2} \mathrm{O}$. Для проведення протравлювання реактор попередньо герметизували двома технологічними фланцевими кришками, виготовленими із вінипласту. Для повної герметизації, фланці корпусу реактора та вінипластові кришки герметизували силіконовими прокладками. Далі, герметизований реактор обертали вздовж повздовжньої осі. Описаний вище процес провели три рази, кожен раз у свіжому розчині травителю, поки поверхня реактора не стала чистою, білою та гладкою.

Після завершення травлення, описаного вище, для нейтралізації залишків розчину, реактор багаторазово промивали водним розчином соди. Після чого також багаторазово промивали чистою водою. Наприкінці обробки, реактор промивали декілька разів дистильованою водою.

Після завершення описаної вище процедури очищення деталей реактора, він був змонтований в установку [3] для проведення досліджень із каталітичної гідратації ацетилену.

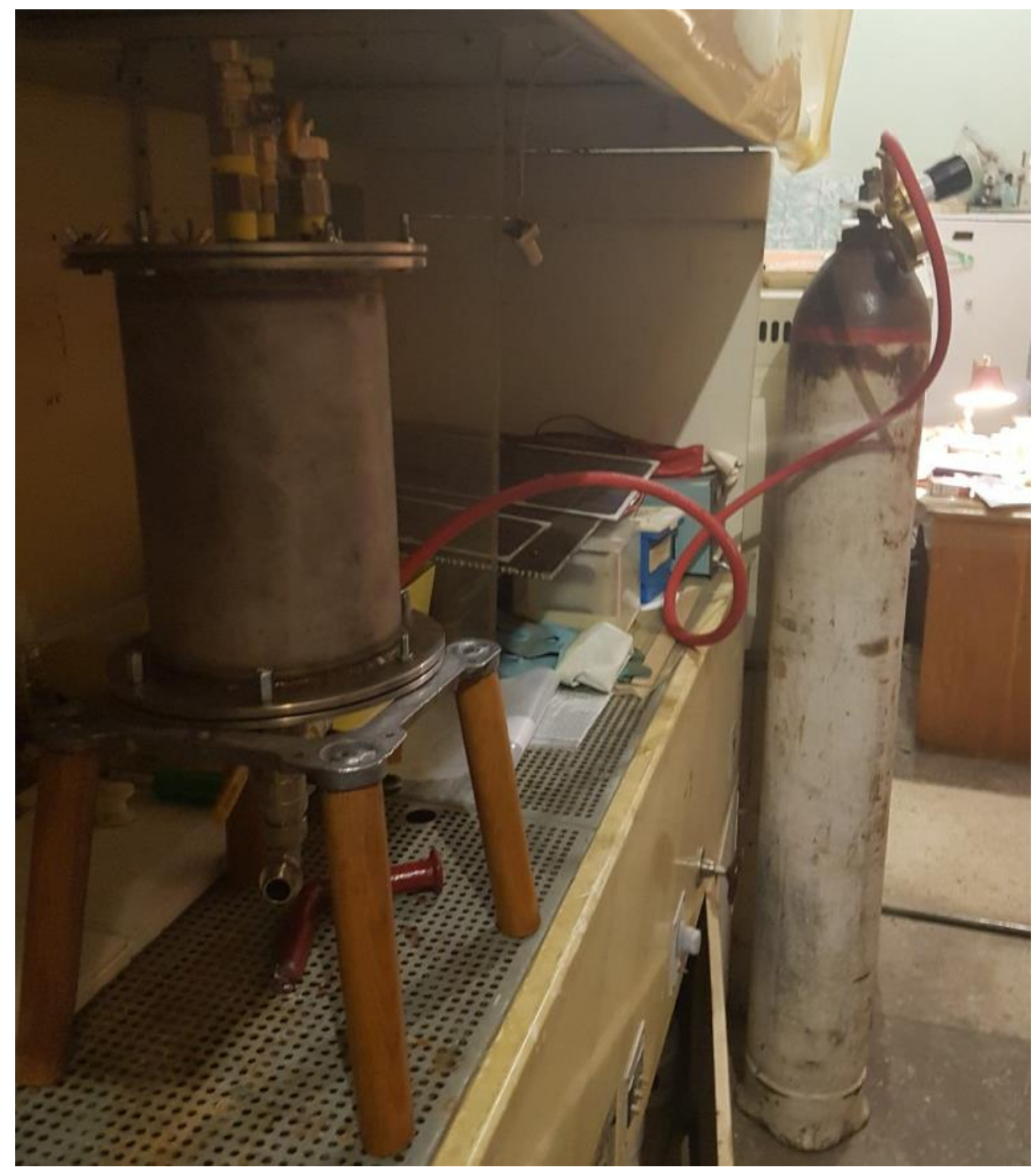

Рисунок 6 - Реактор, змонтований в установку каталітичної гідратації ацетилену.

Для забезпечення роботи реактора в складі зазначеної установки, зокрема у варіанті колонного барботажного реактору, на верхній та нижній кришках була встановлена додаткова арматура. А саме, газові шарові крани, виробництва фірми KOER (Чехія) із зручними подовженими ручками. Для підводу ацетилену були застосовані спеціальні рукави, призначені саме для цього газу. На виході з редуктора та на вході в реактор, 
були додатково встановлені два запобіжники. Герметизація реактору, а саме з’єднання фланців із фланцевими кришками проводилась за допомогою вакуумного силікону.

Висновки. При дослідженні каталітичної гідратації ацетилену із застосуванням металокомплексних каталізаторів на аурумі (I), автором був розроблений, спроектований та виготовлений описаний у статті газорідинний реактор із можливістю зміни гідродинамічної обстановки. Газорідинні реактори подібного типу можуть бути застосовані й в інших подібних процесах, в яких застосовується гомогенний металокомплексний каталіз, невисокі температури та які проводяться при нормальному тиску.

Модульна конструкція, та можливість проведення швидкої зміни гідродинамічної обстановки, дозволяє підібрати оптимальні режими проведення процесу не тільки за температурою, але й за різними гідродинамічними умовами. Описаний у статті реактор, дозволяє виконати важливу частину досліджень стосовно індустріальних процесів в яких застосовуються розчинні гомогенні каталізатори. Роботи, щодо створення таких процесів із застосуванням металокомплексного каталізу в даний час ведуться на факультеті Хімічної інженерії Східноукраїнського національного університету імені Володимира Даля (Україна, м. Сєвєродонецьк).

\section{Л i т е p a т у p a}

1. Соколов В.Н., Доманский И.В., Газожидкостные реакторы. Машиностроение, М., 1976

2. Кохан I.В., Газорідинний реактор для процесів в яких застосовуються гомогенні металокомплексні каталізатори. Технологія-2019, Матеріали XXII міжнародної науково-технічної конференції, м. Сєвєродонецьк

3. Кохан I.В., Лабораторна установка для дослідження каталітичної гідратації ацетилену із застосуванням гомогенного металокомплексного каталізатора. Технологія-2020, Матеріали XXIII міжнародної науковотехнічної конференції, м. Сєвєродонецьк

4. Праусниц Дж., Рид Р., Шервуд Т., Свойства газов и жидкостей. Справочное пособие. Химия, Л., 1982

5. Перри, Джон Г., Справочник инженера-химика, в 2т., пер. с 4-го англ. изд., под общ. ред. акад. Н. М. Жаворонкова и П. Г. Романкова. - Л., Химия, 1969

6. Piet W.N.M. van Leeuwen / Homogeneous Catalysis: Understanding the Art. // Springer. - 2005. ISBN 1-40203176-9

7. Ньюлэнд Ю., Фогт Р., Химия Ацетилена, М., Государственное издательство иностранной литературы, под. ред. и с доп. чл.-корр. АН СССР проф. А. Л. Петрова, 1947

8. Домашнев А.Д. Конструирование и расчет химических аппаратов, М., МАШГИЗ, 1961;

\section{Ref e r e n c e s}

1. Sokolov V.N., Domansky I.V., Liquid-gas reactors. Mashynostroyeniye, M., 1976

2. Ivan Kokhan, Gas-liquid reactor for processes with homogeneous metal complex catalysts. Technology-2019, Proceedings of the XXII International Scientific and Technical Conference, Severodonetsk

3. Ivan Kokhan, Laboratory installation for the study of catalytic hydration of acetylene using a homogeneous metal complex catalyst. Technology-2020, Proceedings of the XXIII International Scientific and Technical Conference, Severodonetsk

4. Robert C. Ried, John M. Prausnitz, Thomas K. Sherwood, The properties of gases and liquids, Third Edition, McGraw - Hill Book Company, 1977

5. John H. Perry, chemical engineers' handbook, Fourth Edition, McGraw - Hill Book Company, 1963

6. Piet W.N.M. van Leeuwen / Homogeneous Catalysis: Understanding the Art. // Springer. - 2005. ISBN 1-40203176-9

7. Julius A. Nieuwland, Richard R. Vogt, The Chemistry of Acetylene, Reinhold Publishing Corporation, 1st edition, 1945

8. Domashnev A.D., Design and calculation of chemical vessels, M., MASHGIZ, 1961;

Объектом научного интереса автора этой статьи является разработка прочессов основного органического синтеза, в которых применяется гомогенный металокомплексних катализ. Для проведения такого типа проиессов, применяют газожидкостные реакторы. В частности, автором исследуется каталитическая гидратация ацетилена на гомогенном катализаторе, растворенном в воде. В таком случае каталитическая система из воды и растворенного в ней катализатора находится в жидкой фазе, через которую барботуеться газ ацетилен. При проведении исследований связанных с инжинирингом указанного процесса решается широкий круг практических задач. В частности необходимость в различных кинетических измерениях, в определении оптимальных режимов проведения процесса, подбора дополнительных растворителей и со-катализаторов. Также важной частью инжиниринга прочесса является выбор оптимальной гидродинамической обстановки для проведения реакции. Для успешного проведения всего этого комплекса исследований, необходимо иметь соответствующие исследовательские реакторные узль. Именно потребность в таких исследовательских газожидкостных реакторах различного типа для проведения 
указанных исследований стала причиной по которой автором был разработан универсальный исследовательский реактор с возможностью изменения гидродинамической обстановки. Таким образом, в этой работе представлены результаты проектирования, конструирования, изготовления и применения в процессах основного органического синтеза указанного реактора. Особенностью реактора, разработанного автором, является применение таких конструктивных решений, которые позволяют изменять гидродинамическую обстановку и проводить исследования по гидродинамике, теплообмена и массообмена газожидкостных реакций при различных условиях. Также в статье приводятся примеры арматурного оформления реактора позволяет эффективно проводить экспериментальные работы и выполнять необходимые технологические операции осуществлять технологические измерения и проводить кинетические исследования.

Ключевые слова: основной органический синтез, гомогенный металокомплексних катализ, каталитическая гидратация ацетилена, газожидкостный реактор, барботирования, газлифт, змейковый реактор.

The object of scientific interest of the author of this article is the development of processes of basic organic synthesis, in which homogeneous metal complex catalysis is used. To carry out this type of process, gas-liquid reactors are used. In particular, the author investigates the catalytic hydration of acetylene on a homogeneous catalyst dissolved in water. In this case, the catalyst system of water and dissolved catalyst is in the liquid phase, through which acetylene gas is bubbled. When conducting research related to the engineering of this process, a wide range of practical problems is solved. In particular, the need for various kinetic measurements, in determining the optimal modes of the process, the selection of additional solvents and co-catalysts. Also an important part of process engineering is the selection of the optimal hydrodynamic environment for the reaction. For the successful implementation of this entire complex of studies, it is necessary to have appropriate research reactor units. It is the need for such research gas-liquid reactors of various types for carrying out these studies that has become the reason why the author has developed a universal research reactor with the ability to change the hydrodynamic environment. Therefore, this paper presents the results of design, construction, manufacture and application in the processes of basic organic synthesis of this reactor. A feature of the reactor developed by the author is the use of such design solutions that allow to change the hydrodynamic environment and to conduct research on hydrodynamics, heat transfer and mass transfer of gas-liquid reactions under different conditions. The article also provides examples of the reinforcement design of the reactor, which allows you to effectively carry out experimental work and perform the necessary technological operations to carry out technological measurements and kinetic studies. Keywords: commodity chemicals, homogeneous metal complex catalysis, catalytic hydration of acetylene, gas-liquid reactor, bubbling, gas lift, snake reactor.

Кохан І. В. - аспірант четвертого курсу навчання, Східноукраїнського Національного Університету ім. В. Даля, Факультет Інженерії, Кафедра Хімічної Інженерії та Екології, спеціальність Хімічні технології органічних речовин, е-таil ivan.v.kokhan@gmail.com 